\title{
Vaccine Intention Determinants Model: A Public Acceptance Study on Covid 19 Vaccination Plan in Central Java
}

\author{
Widiartanto $^{1}$, Amni Zarkasyi Rahman ${ }^{2}$, and Fendy Eko Wahyudi ${ }^{3}$ \\ ${ }^{1}$ Dept. of Business Administration, Faculty of Social and Political Sciences, Universitas Diponegoro \\ ${ }^{2}$ Dept. of Public Administration, Faculty of Social and Political Sciences, Universitas Diponegoro \\ ${ }^{3}$ Dept. of International Relations, Faculty of Social and Political Sciences, Universitas Diponegoro
}

\begin{abstract}
Vaccination, which is often seen as a health policy intervention, has proven to be the most effective at reducing the spread of infectious diseases globally. However, the perception of anti-vaccines, misunderstanding of information related to vaccines, and even doubts about vaccines are still common in the community - no exception related to the COVID-19 global vaccination. Therefore, we need a study that can answer the determinant variable of the COVID-19 vaccination intention, especially in Indonesia. This study answers how personal attitude, subjective norm, and perceived feasibility with religious and media literacy moderation influence the public intention in using the COVID-19 vaccine in Indonesia. This research uses a quantitative research approach, with an explanative research type. We used Theory of Reasoned Action (TRA) and Theory of Planned Behaviour (TPB), and Decomposed Theory of Planned Behaviour (DPTB) as a determinant model with a variable of religiosity and media literacy as a moderating variable for the intention of vaccination COVID-19 in Central Java. This research was conducted in Central Java Province as one of the provinces with the largest population and one of Indonesia's largest number of COVID-19 cases. Data collection was carried out online and offline with 100 respondents.
\end{abstract}

\section{Introduction}

The COVID-19 pandemic has become a global humanitarian health problem. In Indonesia, the COVID-19 pandemic also continues to show an increasing trend [1]. At least 1,803,361 positive cases of COVID-19 have been confirmed in Indonesia until May 2021. This number continues to increase with the number of cases per day as many as 5,862 cases. Even so, $91.8 \%$ of all positive cases of COVID-19 in Indonesia were declared to have recovered successfully [2].

\footnotetext{
* Corresponding author: amnirahman@,lecturer.undip.ac.id
} 
The Indonesian Government also continues to optimize screening and early detection in the community. Of the 34 Provinces of the distribution of COVID-19 cases in Indonesia, three provinces have the highest cases in Indonesia, one of which is Central Java Province. This Province, in May 2021, experienced a spike in positive cases of COVID-19 by $10.9 \%$ over the past three months. This Province is also the third-largest contributor to COVID-19 cases in Indonesia, with 8,515 active cases. However, the number of recovered patients in Central Java Province has increased significantly over the last three months, amounting to 178,189 people [3]. The rise of the COVID-19 recovery rate is quite a positive evaluation for the Government to continue to maximize efforts to fight the COVID-19 pandemic. Various efforts to combat COVID-19 have also been carried out, including a national vaccination for COVID-19.

The Indonesian Government is participating in efforts to combat COVID-19 through this Vaccination. Indonesia has received three types of vaccines from various world vaccine producers. These three vaccines include the Sinovac vaccine, AstraZeneca used in the COVID-19 Vaccination, and which has just arrived from Sinopharm. Indonesian Government said it had received a total of 83,9 million doses of COVID-19 Vaccines until mid-May 2021, with detail: 11 million doses of Sinovac vaccine, 6.4 million doses of AstraZeneca, 1 million doses of Sinopharm. In its implementation, the Government has implemented a national vaccination target of $181,554,465$ of the Indonesian population. Each population has the opportunity to get two doses of vaccine based on WHO recommendations. The Government of Indonesia divides Vaccination into several stages. The first stage is targeted at health workers in Indonesia. Second stage design for public services older people. The third stage is for vulnerable people and areas with a high risk of being exposed to COVID-19. The fourth stage is for the broader public of Indonesia depends on the availability of the existing vaccines. Until mid-May 2021, the Indonesian Government has vaccinated 24.9 million of its citizen, with 1.5 million medical personnel in the first dose and 1.4 million in the second dose. The first dose of elderly is 3.1 million people, and the second dose is 2.1 million people. While the first dose of public officers was 10.4 million people, and the second dose was 6.5 million people [4].

Vaccination efforts, often considered the most effective health policy intervention, have been shown to reduce the global spread of infectious diseases [7]. However, amidst various proven scientific studies, global vaccination efforts still face obstacles. The problems that arise are pretty diverse, ranging from anti-vaccines, misconceptions about vaccines, and even doubts about vaccines still widely found in public.[8] [9]. Indonesia has the most extensive vaccination program against COVID-19 in all of Southeast Asia, with a plan to inoculate 181.5 million people [10].

During the first batch vaccination process, Indonesia has joined an international partnership with the COVAX Facility that ensures equitable distribution of COVID-19 vaccines worldwide. The COVAX facility has allocated 11 million vaccine doses to Indonesia to help Indonesia reach its target to vaccinate 181 million people with health workers, frontline workers, older adults, and vulnerable populations. The allocated vaccines from COVAX Facility will continue to arrive until May 2021 [11]. However, the vaccination plan would still need much effort to reach the targeted amount because Health Minister Budi Gunadi Sadikin has noted that many Indonesians were still afraid of the vaccine [13]. Acceptance of the public in Indonesia toward the vaccination plan is one crucial factor determining whether or not the plan reached the targeted amount of people getting vaccinated.

What should be noted here is that vaccine acceptance is quite volatile here in Indonesia. With much information rapidly circulated about the efficacy of a specific type of vaccine used by the Government of Indonesia during the vaccination program, many citizens are still in doubt whether or not they would take the vaccine. One of the most populous provinces in 
Indonesia, Central Java, has officially begun the second wave of vaccination plan targeting 1 thousand people getting injected per day. However, for some reason, there is an indication that the realization might not meet the target [15]. There is a high tendency that citizens in Central Java stand against the vaccination program planned by the Government even though it has been shown by research that the type of vaccine used by the Government has a highrate efficacy against the virus [16]. As one of the biggest and populous provinces, public acceptance of the COVID-19 vaccination plan in Central Java is essential in determining whether or not the targeted number of people vaccinated in Indonesia can be reached. Moreover, further research should be done about public acceptance of the COVID-19 vaccine, especially in Central Java. In the end, it is expected that this research could contribute to giving insight into the effort of studying public acceptance toward the COVID19 vaccination plan in Indonesia in general.

Previous studies related to Vaccination Intention can be classified into studies related to the Determination of Vaccination Intention. The majority of previous studies used the Behavioral Theories approach, primarily focusing on Theory of Planned Behavior (TPB) and Theory of Reasoned Action (TRA), to provide an explanation of the certainty of vaccination intentions in a society [17] [18] [19]. Other studies have also indicated that the variable of religiosity can also influence views on vaccine utilization [19]. Some belief systems spread different perspectives on Vaccination. Religious unwillingness and belief in vaccines are based on (1) ethical dilemmas related to the use of tissue cells by humans to make vaccines, and (2) the belief that the human body is sacred, should not accept certain chemicals or blood or tissues and must be recovered by God and other natural means. From all existing literature related to the Determination of intention in Vaccination above, no research has been found that focuses on the Determination of intention in Vaccination for COVID-19, especially by taking studies from an Asian perspective. Starting from the previous explanation, this research is applied to determine the determinant model of COVID-19 Vaccination in Central Java, Indonesia. This research is essential to do, foremost to determine what variables affect the intention in vaccinating the society, particularly those related to the COVID-19 vaccination plan in Indonesia. This research shows that TPB and TRA can explain intention factors in the COVID-19 Vaccination in Central Java. Accordingly, this research result can be used as input or recommendation for Indonesian policymakers to control the COVID-19 pandemic.

\section{Methods}

The data used in this study were primary data obtained from the online distributed questionnaire to the 100 respondents who live in Semarang city, with the sample requirements such as being 18-65 years old, waiting to be vaccinated against COVID-19 or have already been COVID-19 vaccinated and willing to fill the Online questionnaire. Data analysis was carried out by using SmartPLS version 3.2.2 software.

\subsection{Variable and Measurement}

The measurement scale in this study on the variables of attitude towards vaccination behaviour, subjective norms of Vaccination, and behavioural control of perceptions and intentions of using vaccines, religiosity, and media literacy use a Likert scale of 1-5, where each item is provided with a range of extreme angles of strongly agree and strongly disagree. Agree, based on proxies of the expert's scale of measurement. This research measures the attitude construct towards vaccination behaviour in 3 things: perception of the benefits of Vaccination, perception of the risk of Vaccination, and perception of the pleasure of 
vaccinating. Moreover, to measure the subjective norm construct of Vaccination, this research looks at four indicators: the influence of close friends, the influence of close family, the influence of superiors or people who are considered necessary, and the influence of the social environment. The construct of perceived behavioural control is measured from 3 things: self-efficacy in carrying out vaccinations, the condition of vaccination resource facilities, and perceived controllability of using vaccines. Measurement of the construct of intention to use the vaccine is seen from 3 things: the expectation of using, desire to use, and the intention to use the vaccine. In this research, we adopt the construct of religiosity from The Duke University Religion Index (DUREL), including the religious approach in solving life problems and religious views on the COVID-19 disaster. Also, the construct of media literacy variable, we assess the respondent point of view regarding: the level of trust in news on social media, the process of comparing digital media information with life experiences, and attitudes towards broadcast messages.

\subsection{Data Analysis}

The results of the interpretation of the model evaluation were presented in the form of a table consisting of testing the measurement model in the form of the results of the validity and reliability tests and testing the structural model in the form of r-square and f-square tests. We use SmartPLS software version 3.3.2 for analyzing the collected data. In this research, we test and evaluate the model by testing the validity and reliability, which includes two stages: evaluating the measurement model (outer model) and evaluating the structural model (inner model). The model tested were the influence of attitudes towards vaccination behaviour (X1), subjective norms of Vaccination (X2), and perceived behavioural control (X3) on the intention to use vaccines $(\mathrm{Y})$, with the moderator variables being religiosity $(\mathrm{Z} 1)$ and media literacy $(\mathrm{Z} 2)$.

\section{Results}

\subsection{Variable Description}

This analysis was conducted to obtain an overview of the data collected on each variable. Based on these calculations, the average was calculated, which was then classified. On the variables of attitude towards vaccination behaviour, subjective norms of Vaccination perceived behavioural control, intention to use vaccines, religiosity, and media literacy for the average value were classified on five criteria: very not good, not good, quite good, and very good..

Table 1. Variable Description.

\begin{tabular}{|c|c|c|}
\hline Variable & Average & Criteria \\
\hline $\begin{array}{c}\text { Attitude towards vaccination behavior } \\
\text { (X1) }\end{array}$ & 3,22 & Quite good \\
\hline $\begin{array}{c}\text { Subjective norms of Vaccination (X2) } \\
\text { Perceived behavioral control (X3) }\end{array}$ & 3,54 & Quite good \\
\hline Intention to use the vaccines (Y) & 3,88 & Quite good \\
\hline Religiosity (Z1) & 3,31 & Quite good \\
\hline Media literacy (Z2) & 3,33 & Quite good \\
\hline
\end{tabular}


Source: the calculated primary data, 2021.

\subsection{Measurement Model Analysis and PLS Analysis}

Testing the measurement model was done through PLS in two steps. The first step was testing the outer model by testing the validity and reliability of the constructor-forming indicators. Then, a convergent validity test was done by looking at the Average Variance Validity (AVE) value. The AVE value must be greater than 0.5 as large as the cross-loading, which means the factor must explain at least half the variation of the indicator represented [16]. An AVE value below 0.5 means that the error variation exceeds the described variation. Table 2 demonstrates the final results of the convergent validity test:

Table 2. Final Convergent Validity Test Results.

\begin{tabular}{|c|c|c|c|c|}
\hline Variable & AVE Value & $=$ & $\mathbf{0 , 5}$ & Conclusion \\
\hline $\begin{array}{c}\text { Attitude towards vaccination } \\
\text { behavior (X1) }\end{array}$ & 0,743 & $>$ & 0,5 & Valid \\
\hline $\begin{array}{c}\text { Subjective norms of vaccination } \\
(\mathrm{X} 2)\end{array}$ & 0,667 & $>$ & 0,5 & Valid \\
\hline Perceived behavioral control (X3) & 0,526 & $>$ & 0,5 & Valid \\
\hline Intention to use the vaccines (Y) & 0,930 & $>$ & 0,5 & Valid \\
\hline Religiosity (Z1) & 1,000 & $>$ & 0,5 & Valid \\
\hline Media literacy (Z2) & 0,502 & $>$ & 0,5 & Valid \\
\hline
\end{tabular}

Source: The calculated primary data, 2021

The discriminant validity in this study was tested using the Fornell-Larcker criteria. The Fornell-Lacker criteria require that the square root value of AVE must be higher than its correlation value with any latent variable. This means that the variation shared with the indicator block for any latent variable is greater than the variation shared with other latent variables [16]. Table 3 shows the results of discriminant validity testing:

Table 3. Discriminant Validity Test Results Model 2.

\begin{tabular}{|c|c|c|c|}
\hline Variable & $\begin{array}{c}\text { AVE } \\
\text { Value }\end{array}$ & $\begin{array}{c}\text { Square Root } \\
\text { AVE Value }\end{array}$ & Conclusion \\
\hline $\begin{array}{c}\text { Attitude towards vaccination behavior } \\
(\mathrm{X} 1)\end{array}$ & 0,743 & 0,861 & Valid \\
\hline Subjective norms of vaccination (X2) & 0,667 & 0,817 & Valid \\
\hline Perceived behavioral control (X3) & 0,526 & 0,725 & Valid \\
\hline Intention to use the vaccines (Y) & 0,930 & 0,964 & Valid \\
\hline Religiosity (Z1) & 1,000 & 1 & Valid \\
\hline Media literacy (Z2) & 0,502 & 0,708 & Valid \\
\hline
\end{tabular}

Source: The calculated primary data, 2021

From table 3, it can be seen that all variables have an AVE square value more significant than the AVE value, so it can be concluded that all constructs in the research model meet the discriminant validity criteria. 
Reliability is the consistency value of the measuring instrument in measuring the same symptoms. The questionnaire is reliable if the answers to the questions are consistent from time to time. The reliability test was carried out with the help of the SmartPLS software version 3.3.2 with composite reliability and Cronbach's alpha test tools. The assessment standard used was composite reliability, similar to other reliability assessment standards, including Cronbach's alpha. The value of composite reliability varies from 0 to 1 , with 1 being the perfect reliability estimate. Furthermore, to measure reliability with internal consistency, the composite reliability value must be greater than 0.7 (0.6-0.7), which is still allowed for explanatory research [17]. The following was the results of composite reliability testing:

Table 4. Composite Reliability Test Results.

\begin{tabular}{|c|c|c|c|c|}
\hline Variable & $\begin{array}{c}\text { Composite } \\
\text { Reliability Value }\end{array}$ & $=$ & $\mathbf{0 , 7}$ & Conclusion \\
\hline Attitude towards vaccination behavior (X1 & 0,919 & $>$ & 0,7 & Valid \\
\hline Subjective norms of vaccination (X2) & 0,886 & $>$ & 0,7 & Valid \\
\hline Perceived behavioral control (X3) & 0,846 & $>$ & 0,7 & Valid \\
\hline Intention to use the vaccines (Y) & 0,975 & $>$ & 0,7 & Valid \\
\hline Religiosity (Z1) & 1,000 & $>$ & 0,7 & Valid \\
\hline Media literacy (Z2) & 0,751 & $>$ & 0,7 & Valid \\
\hline
\end{tabular}

Source: The calculated primary data, 2021

Based on the table above, it can be seen that all variables in the research model were declared reliable because they have a composite reliability value of more than 0.7 . The variable that has the highest composite reliability value was the religiosity variable with an excellent composite reliability value of 1,000 . The variable that has the lowest composite reliability value was the media literacy variable, with a composite reliability value of 0.751 .

In the second step, the researcher conducted an inner or structural model test, assessed through $\mathrm{R}$-square and $\mathrm{f}$-square tests. $R$-square is the overall effect size measured for the structural model. Garson (2016) categorizes the R-square value into 3 categories, namely strong $(>0.67)$, moderate $(>0.33-0.67)$, and weak $(>0.19-0.33)$. While f-square is an effect size that explains how big the proportion of variance is not explained and calculated by changes in R-square [16]. Cohen grouped the f-square values into three categories, namely small effects (0.02), medium effects (0.15), and large effects $(0.35)$ [16].

Table 5. R-Square and R-Square Adjusted Model and Effect Size for Path Coefficient Model.

\begin{tabular}{|c|c|c|}
\hline Variable & R-Square & R-Square Adjusted \\
\hline Intention to use the vaccines & 0,691 & 0,652 \\
\hline Variable & $\boldsymbol{f}$-square & Interpretasi \\
\hline $\begin{array}{c}\text { Attitude towards vaccination } \\
\text { behavior }\end{array}$ & 0,232 & Small \\
\hline $\begin{array}{c}\text { Subjective norms of } \\
\text { vaccination }\end{array}$ & 0,000 & Medium \\
\hline Perceived behavioral control & 0,215 & Small \\
\hline Religiosity & 0,053 & 0,802 \\
\hline \multicolumn{2}{|c|}{} \\
\hline Goodness of Fit (GoF) Value & Goodness of Fit (GoF) Value \\
\hline
\end{tabular}


Source: The calculated primary data, 2021

Based on the table above, the R-Square value of the vaccine's intention variable was 0.691 , so it was included in the strong category $(>0.67)$. This value means that the research model successfully explained $69.1 \%$ of the vaccine's intention variable variance. However, one variable did not have any effect strength $(0.000)$ other than that described by R-square, namely the subjective norm of Vaccination. In addition, the attitude variable towards vaccination behaviour can explain $23.2 \%$ of the variance, which the R-square did not explain. The perceived behavioural control variable can explain $21.5 \%$ of the variance; the religiosity variable can explain $5.3 \%$ of the variance. In comparison, the media literacy variable can only explain $4.1 \%$ of the variance, which R-square did not explain. Referring to Garson's categorization, the goodness of fit value of 0.802 was more significant than 0.36 , so that it was included in the high eligibility category. This value indicated that the research model was fit and feasible to use.

\subsection{Hypothesis Testing}

Hypothesis testing was done by using the resampling technique with Bootstrapping method on SmartPLS version 3.3.2. Hypothesis testing in this study through the direct effect procedure to test the direct effect. The relationship between variables can be seen through the value of t-statistics, p-value, and original sample on the output Path Coefficient. The hypothesis is accepted if the p-value is less than 0.05 or $5 \%$. The p-value is used to see the significance of the relationship between variables.

\subsubsection{Direct Effect Test}

The direct effect test between variables was carried out through the resampling technique with the bootstrapping method. In this study, the direct effect test was conducted using Basic Bootstrapping and two-tailed hypothesis testing with a significance level of $5 \%$. The following were the results of the direct influence test of the Path Coefficient through the Bootstrapping method.

Based on the data in Table 7, it can be seen that the effect of the attitude variable on vaccination behaviour (STP), perceived behavioural control (KPP), and religiosity (REG) on the intention to use the vaccine (IV) each has a p-value of less than 0.05 and positive original sample values. This showed that the variables of attitude towards vaccination behaviour, perceived behavioural control, and religiosity had a significant and positive effect on intentions to use vaccines. The moderating effect of the media literacy variable (LM) on the relationship between the attitude variable towards vaccination behaviour (STP) and the intention to use the vaccine (IV) has a p-value of less than 0.05 with a negative original sample value. This showed that the moderating effect of the media literacy variable had a significant adverse effect on the relationship between the attitude variable towards vaccination behaviour and the intention to use the vaccine. 
The results of the model hypothesis testing carried out were shown in Figure 1. below:

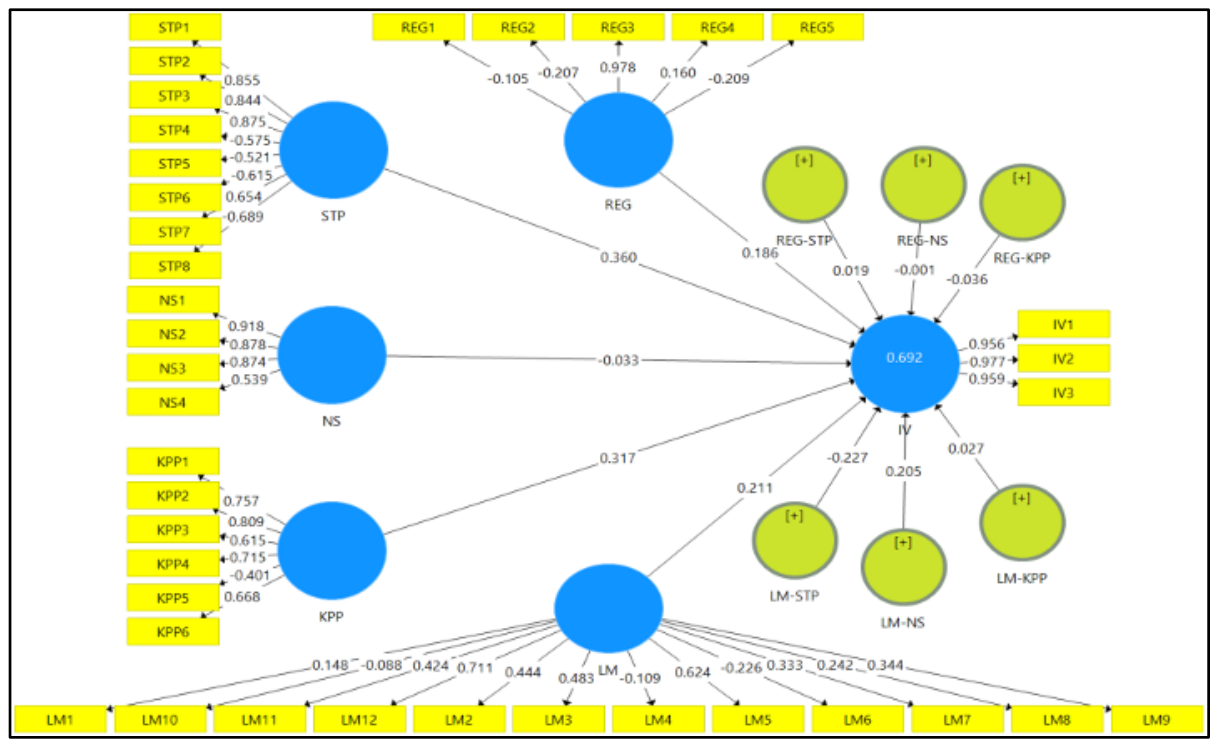

Fig. 1. Model Hypothesis Test.

Source: The calculated primary data, 2021.

Table 6. Test Results of Direct Effect of Output Path Coefficient Model.

\begin{tabular}{|c|c|c|c|c|c|c|}
\hline & $\begin{array}{c}\text { Original } \\
\text { Sample }\end{array}$ & $\begin{array}{c}\text { Sample } \\
\text { Mean }\end{array}$ & $\begin{array}{c}\text { Standard } \\
\text { Deviation }\end{array}$ & $\begin{array}{c}\boldsymbol{T} \\
\text { Statistics }\end{array}$ & $\begin{array}{c}\boldsymbol{P} \\
\text { Values }\end{array}$ & Intepretation \\
\hline STP -> IV & 0,382 & 0,363 & 0,087 & 4,394 & $\mathbf{0 , 0 0 0}$ & $\begin{array}{c}\text { Significantly } \\
\text { Positive }\end{array}$ \\
\hline NS -> IV & $-0,012$ & 0,002 & 0,099 & 0,124 & 0,901 & Not Significant \\
\hline KPP -> IV & 0,323 & 0,325 & 0,071 & 4,555 & $\mathbf{0 , 0 0 0}$ & $\begin{array}{c}\text { Significantly } \\
\text { Positive }\end{array}$ \\
\hline REG -> IV & 0,150 & 0,146 & 0,075 & 2,011 & $\mathbf{0 , 0 4 5}$ & $\begin{array}{c}\text { Significantly } \\
\text { Positive }\end{array}$ \\
\hline REG-STP -> IV & 0,186 & 0,160 & 0,098 & 1,898 & 0,058 & Not Significant \\
\hline REG-NS -> IV & $-0,025$ & $-0,008$ & 0,087 & 0,281 & 0,779 & Not Significant \\
\hline REG-KPP -> IV & $-0,062$ & $-0,063$ & 0,070 & 0,880 & 0,380 & Not Significant \\
\hline LM -> IV & 0,140 & 0,154 & 0,068 & 2,045 & $\mathbf{0 , 0 4 1}$ & $\begin{array}{c}\text { Significantly } \\
\text { Positive }\end{array}$ \\
\hline LM-STP -> IV & $-0,278$ & $-0,240$ & 0,097 & 2,859 & $\mathbf{0 , 0 0 4}$ & $\begin{array}{c}\text { Significantly } \\
\text { Positive }\end{array}$ \\
\hline LM-NS -> IV & 0,245 & 0,205 & 0,107 & 2,282 & $\mathbf{0 , 0 2 3}$ & $\begin{array}{c}\text { Significantly } \\
\text { Positive }\end{array}$ \\
\hline LM-KPP -> IV & $-0,029$ & $-0,037$ & 0,073 & 0,406 & 0,685 & Not Significant \\
\hline
\end{tabular}

Source: The calculated primary data, 2021

Variable subjective norm of Vaccination (NS), moderating effect of religiosity variable on attitudes towards vaccination behaviour (REG-STP), moderating effect of religiosity variable on attitudes towards the subjective norm of Vaccination (REG-NS), moderating effect of religiosity variable on perceived behavioural control (REG-NS) KPP), and the moderating effect of media literacy variables on perceived behavioural control (LM-KPP) 
had a p-value of more than 0.05 . Therefore, these variables had no significant effect on the variable of intention to use the vaccine.

Table 7. Moderation Test Results.

\begin{tabular}{|c|c|c|c|}
\hline & Variable Influence & Moderation Effect & Conclusion \\
\hline REG-KPP -> IV & Significant & Not Significant & Predictor \\
\hline REG-NS -> IV & Significant & Not Significant & Predictor \\
\hline REG-STP -> IV & Significant & Not Significant & Predictor \\
\hline LM-KPP -> IV & Significant & Not Significant & Predictor \\
\hline LM-STP -> IV & Significant & Significant & Pseudo \\
\hline LM-NS -> IV & Significant & Significant & Pseudo \\
\hline
\end{tabular}

Source: The calculated primary data, 2021

As presented in Table 7, the moderation test results showed that the religiosity variable was of the predictor moderation type, which meant that the religiosity variable was more suitable as a predictor variable than a moderating variable. On the other hand, the media literacy variable was of pseudo-moderation type, which meant that the media literacy variable was not clearly (pseudo) its position between the predictor variable or the moderating variable.

\section{Discussion}

In the first hypothesis showed that attitudes towards vaccination behaviour had a positive and significant effect on increasing the vaccine's intention. This result corresponds with Dillard's (2011) study, which found that attitudes, norms, and PBC were strong predictors of vaccination intention. In addition, Dube also revealed that three constructs (attitude, norm, and PBC) significantly predicted intention to vaccinate children among parents [18].

The second hypothesis showed that the subjective norm of Vaccination had no impact on using the vaccine. It was indicated that the subjective norm of Vaccination could not explain the variable of intention to use the vaccine. This was contrary to the results of Dillard [19] and Dube [18], which revealed that three constructs (attitude, norm, and PBC) significantly predicted intention to vaccinate children among parents. Conclusion: there was a phenomenon that caused the subjective norm of Vaccination to be leveraged for the intention to use vaccines. Based on the descriptive analysis, it can be seen that the subjective norm of the vaccination variable had an average value of 3.54 so that it was included in the reasonably high category.

Nevertheless, there was still one indicator that had an average value below the average value of the variable, that is, the indicator regarding the influence of the social environment. This variable had an average value of 2.9. It meant that the average respondent's answer was not depressed or felt no pressure from the social environment on using the vaccine. In other words, there was freedom from the community to participate or not to participate in the vaccination program.

The third hypothesis about the effect of perceived behavioural control on the intention to use the vaccine showed a positive and significant effect. This was in line with Dillard's and Dube's [18] results [19]. However, on the other hand, it contradicted some research results, where the control of perceived behaviour was questioned in several studies [20-23]. For example, in the context of the research in university, students' intention to receive required vaccinations including Hepatitis A and B as well as HPV, Britt, Hatten, and Chappuis [23] found that only attitudes and norms significantly predicted intention across various vaccination behaviours; Perceived behavioural control did not contribute to predicting intention significantly. Similarly, in students' learning intentions to receive influenza 
vaccination, Cornally [22] suggested that the TPB measure explained $42 \%$ of the variance, meaning that perceived behavioural control did not make a statistically significant contribution.

The fourth, fifth, and sixth hypotheses about the moderating effect of the religiosity variable on the relationship between attitudes towards vaccination behaviour, subjective norms of Vaccination, and perceived behavioural control on the intention to use vaccines showed that there were significant effects of the variables but with an insignificant moderating effect. This research concludes that the religiosity variable was more suitable to be a predictor variable on the intention to use the vaccine, rather than being a moderator variable. In this study, the effect of the religiosity variable on the intention to use the vaccine was positive and significant, meaning that the more religious a person is, the higher his intention to use the vaccine. This was contrary to the results of Olagoke's study [24], where religiosity has a significant and negative effect on the intention to vaccinate against COVID19. The results of Olagoke's research confirm the principles of religious coping, which link responses to stressful life events with external HLOC so that crises can be viewed as an act of God that cannot be changed or prevented [25].

On the contrary, this research shows that the more religious a person is, the more they generally agree on Vaccination and health measure to solve and prevent COVID-19. This result needs further inquiries. Since in the context of Indonesian society nowadays, there is the vast stereotype that shows religiosity as the opposite of logical view on preventing and mitigating COVID-19, including vaccination program by the Indonesian Government.

For the ninth hypothesis, regarding the effect of media literacy as a moderating variable on the relationship between Perceived Behavioral Control and intention to use vaccines, it was seen that the media literacy variable was a predictor variable. This was also supported by the results of a digital literacy survey conducted by the Katadata Insight Center in collaboration with the Ministry of Communication and Information (Kominfo) by capturing 1,670 respondents from 34 provinces in Indonesia where the majority of respondents stated that social media was the most widely accessed media to find information. 28]. Whatever media the community chooses in seeking information, will be a message that can change people's views [29].

While in the seventh and eighth hypotheses, it can be seen that the moderating variable of media literacy had a significant effect on the relationship between attitudes towards vaccination behaviour and the subjective norm of Vaccination on intentions to use vaccines, with a significant moderating effect, so it can be concluded that the media literacy variable was a pseudo moderating variable.

\section{Conclusion}

Several variables positively and significantly affect the intention to use the COVID-19 vaccines in Central Java, supporting our model in this research. The variables were attitudes towards vaccination behaviour and perceived behavioural control. Meanwhile, religiosity, which was initially a moderating variable in our model, becomes a predictor variable. Furthermore, the religiosity variable positively and significantly influenced the intention to use the COVID-19 vaccines. Based on these findings, we can conclude that the more religious a person is, the higher the intention to Vaccination.

On the other hand, the subjective norm had a small average value. There were no strong relations from the norms (close friends, close family, superiors, or people considered essential and the social environment) for shaping a person's intention of COVID-19 Vaccination.

Another finding of this study was that various vaccination socializations effectively increased Intention in Vaccination, especially for generation $\mathrm{Z}$ and millennials in the age 
range of 20-40. Therefore, practically we recommend massive socialization in various media to increase intention in COVID-19 Vaccination. However, academic research is needed to explore the relation between religiosity and a logical view to the mitigating pandemic. Then, hopefully, we could be prepared and see it clearly for the next global health crisis.

\section{References}

1. www.who.int, "WHO Coronavirus Disease (COVID-19) Dashboard," 2020. htttps://covid19.who.int/ (accessed Oct. 29, 2020).

2. COVID19.go.id, "Peta Sebaran COVID-19," 2021. https://covid19.go.id/peta-sebaranCOVID19 (accessed May 28, 2021).

3. corona.jatengprov.go.id, "Statistik Kasus COVID-19 Jawa Tengah," 2021. https://corona.jatengprov.go.id/data (accessed May 28, 2021).

4. www.kemkes.go.id, "8 Juta Dosis Vaksin Sinovac Tiba di Indonesia," 2021. https://www.kemkes.go.id/article/view/21052600003/8-juta-dosis-vaksin-sinovac-tibadi-indonesia.html (accessed May 28, 2021).

5. www.unicef.org, "Vaccination and Immunization Statistics - UNICEF DATA," 2020. https://data.unicef.org/topic/child-health/immunization/ (accessed Oct. 29, 2020).

6. X. Xiao and R. M. Wong, "Vaccine hesitancy and perceived behavioral control: A metaanalysis.," Vaccine, vol. 38, no. 33, pp. 5131-5138, Jul. 2020, doi: 10.1016/j.vaccine.2020.04.076.

7. www.kemlu.go.id, "Indonesia Launches First COVID-19 Vaccination Program," 2021. https://kemlu.go.id/madrid/en/news/10666/indonesia-launches-first-COVID-19vaccination-program (accessed May 28, 2021).

8. www.who.int, "Indonesia received the first batch of COVID-19 vaccines from the COVAX Facility," 2021. https:/www.who.int/indonesia/news/detail/09-03-2021indonesia-received-the-first-batch-of-COVID-19-vaccines-from-the-covax-facility (accessed May 28, 2021).

9. www.france24.com, "Indonesia kicks off second wave of COVID-19 vaccinations," 2021. www.france24.com/en/live-news/20210217-indonesia-kicks-off-second-waveof-COVID-19-vaccinations (accessed May 28, 2021).

10. www.medcom.id, "Central Java Begins Second Wave of COVID-19 Vaccinations," 2021. https://www.medcom.id/english/national/8kolQ9YK-central-java-begins-secondwave-of-COVID-19-vaccinations (accessed May 29, 2021).

11. www.thejakartapost.com, "Studies Find Vaccines Working As Indonesians Tiptoe Around Adverse Events." https:/www.thejakartapost.com/news/2021/05/26/studiesfind-vaccines-working-as-indonesians-tiptoe-around-adverse-events.html (accessed May 28, 2021).

12. N. T. Ratanasiripong, A.-L. Cheng, and M. Enriquez, "What college women know, think, and do about human papillomavirus (HPV) and HPV vaccine.," Vaccine, vol. 31, no. 10, pp. 1370-1376, Feb. 2013, doi: 10.1016/j.vaccine.2013.01.001.

13. M. Fishbein and J. N. Cappella, "The Role of Theory in Developing Effective Health Communications," J. Commun., vol. 56, no. s1, pp. S1-S17, Aug. 2006, doi: https://doi.org/10.1111/j.1460-2466.2006.00280.x.

14. S. Mahdi, O. Ghannam, S. Watson, and A. I. Padela, "Predictors of Physician Recommendation for Ethically Controversial Medical Procedures: Findings from an 
Exploratory National Survey of American Muslim Physicians.," J. Relig. Health, vol. 55, no. 2, pp. 403-421, Apr. 2016, doi: 10.1007/s10943-015-0154-y.

15. M. Fishbein and I. Ajzen, "Belief, attitude, intention, and behavior: An introduction to theory and research," 1977.

16. G. D. Garson, "Partial least squares: regression \& structural equation models Asheboro," North Carolina Stat. Assoc. Publ., 2016.

17. M. Sholihin and D. Ratmono, Analisis SEM-PLS dengan WarpPLS 7.0 untuk Hubungan Nonlinier dalam Penelitian Sosial dan Bisnis. Penerbit Andi, 2021.

18. E. Dubé et al., "Measuring vaccine acceptance among Canadian parents: A survey of the Canadian Immunization Research Network.," Vaccine, vol. 36, no. 4, pp. 545-552, Jan. 2018, doi: 10.1016/j.vaccine.2017.12.005.

19. J. P. Dillard, "An application of the integrative model to women's intention to be vaccinated against HPV: implications for message design.," Health Commun., vol. 26, no. 5, pp. 479-486, 2011, doi: 10.1080/10410236.2011.554170.

20. C. W. Wheldon, E. M. Daley, E. R. Walsh-Buhi, J. A. Baldwin, A. G. Nyitray, and A. R. Giuliano, "An integrative theoretical framework for HPV vaccine promotion among male sexual minorities," Am. J. Mens. Health, vol. 12, no. 5, pp. 1409-1420, 2018.

21. H. P. Catalano, A. P. Knowlden, D. A. Birch, J. D. Leeper, A. M. Paschal, and S. L. Usdan, "Using the Theory of Planned Behavior to predict HPV vaccination intentions of college men.," J Am. Coll. Health, vol. 65, no. 3, pp. 197-207, Apr. 2017, doi: 10.1080/07448481.2016.1269771.

22. N. Cornally et al., "Student nurses' intention to get the influenza vaccine.," Br. J. Nurs., vol. 22, no. 21, pp. 1207-1211, Nov. 2013, doi: 10.12968/bjon.2013.22.21.1207.

23. R. K. Britt, K. N. Hatten, and S. O. Chappuis, "Perceived behavioral control, intention to get vaccinated, and usage of online information about the human papillomavirus vaccine," Heal. Psychol. Behav. Med., vol. 2, no. 1, pp. 52-65, Jan. 2014, doi: 10.1080/21642850.2013.869175.

24. A. A. Olagoke, O. O. Olagoke, and A. M. Hughes, "Intention to Vaccinate Against the Novel 2019 Coronavirus Disease: The Role of Health Locus of Control and Religiosity.," J. Relig. Health, vol. 60, no. 1, pp. 65-80, Feb. 2021, doi: 10.1007/s10943020-01090-9.

25. J. Sinding Bentzen, "Acts of God? Religiosity and natural disasters across subnational world districts," Econ. J., vol. 129, no. 622, pp. 2295-2321, 2019.

26. J. Y. Cuan-Baltazar, M. J. Muñoz-Perez, C. Robledo-Vega, M. F. Pérez-Zepeda, and E. Soto-Vega, "Misinformation of COVID-19 on the Internet: Infodemiology Study.," JMIR public Heal. Surveill., vol. 6, no. 2, p. e18444, Apr. 2020, doi: 10.2196/18444.

27. R. Kouzy et al., "Coronavirus Goes Viral: Quantifying the COVID-19 Misinformation Epidemic on Twitter.," Cureus, vol. 12, no. 3, p. e7255, Mar. 2020, doi: 10.7759/cureus. 7255 .

28. https://databoks.katadata.co.id/, "Masyarakat Paling Banyak Mengakses Informasi dari Media Sosial," 2020. https://databoks.katadata.co.id/datapublish/2020/11/23/masyarakat-paling-banyakmengakses-informasi-dari-media-sosial (accessed May 29, 2021).

29. M. McLuhan, The medium is the message. Routledge, 2017. 